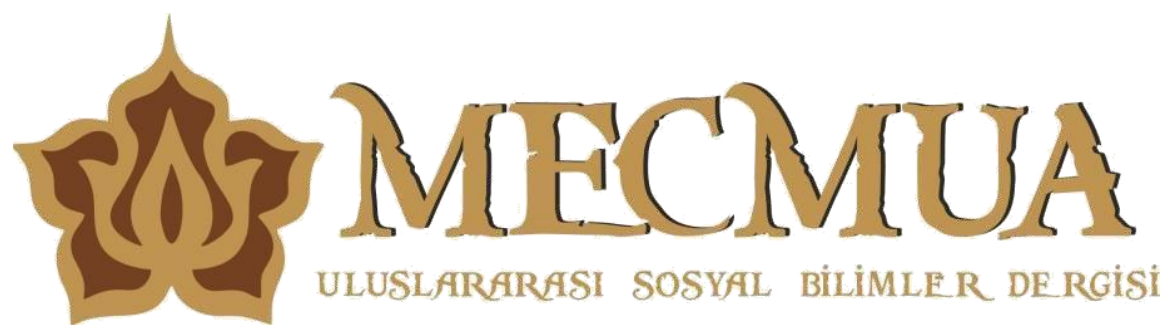

Bahar 2019, Yıl: 4, Sayı: 7, ss. 112-116

Doi Number: https://dx.doi.org/10.32579/mecmua.536411

Araştırma Makalesi / Research Article

$\underline{\text { Yayın Süreci / Publication Process }}$

Yükleme Tarihi: 01.03.2019 / Kabul Tarihi: 16.03.2019

Sezgi DURGUN*

\title{
SOKAĞIN HAFIZASINI TUTMAK, HAFIZANIN SOKAKLARINDA GEZMEK: KUZGUNCUK ÖRNEĞİ
}

\begin{abstract}
Öz
Amy Mills'in Koç Üniversitesi yayınlarından 2014 yılında "Hafızanın Sokakları: İstanbul'da Peyzaj, Hoşgörü ve Ulusal Kimlik" adıyla basılan araştırması millileşen bir kentin kültürel coğrafyaları üzerine bizi eleştirel bir geziye çıkarıyor. Makalede kitabın eleştirel bir incelemesi yapılmaktadır. Özellikle Osmanlı imparatorluğundan bugüne gelirken İstanbul'un kozmopolit mahallelerinde yaşanan dönüşüm ve bunun tarihsel ve coğrafi yansımaları ele alınmaktadır. Kuzguncuk örneğinde özellikle millileşen kent ve kent kültürünün analizi yapılmıştır.
\end{abstract}

Anahtar Kelimeler: kuzguncuk,mahalle,sokak,kimlik,hafiza

\section{KEEPING THE MEMORY OF THE STREETS}

\begin{abstract}
This is a critical review of a book titled as "Hafizanın Sokakları: İstanbul'da Peyzaj, Hoşgörü ve Ulusal Kimlik" by Amy Mills published by Koç Üniversity publications in 2014 . Her research is evaluated in the context of the Ottoman past and its spatial traces as it can be seen in the old cosmopolitan neighbourhoods in İstanbul. Kuzguncuk
\end{abstract}

* ID Dr. Öğr. Üyesi, Marmara Üniversitesi, Siyasal Bilgiler Fakültesi, İngilizce Siyaset Bilimi ve Uluslararası İlişkiler Bölümü. sezgi2005@gmail.com. 
is one these neighbourhoods that has a special place in the history and geography of Turkey and İstanbul. In my review I specifically focused on the nationalization process that had occured in the urban cultural setting of Kuzguncuk.

Keywords: Memory,identity,street,Kuzguncuk

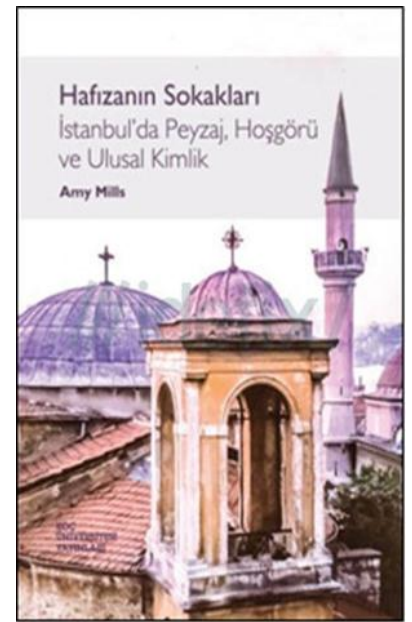

Kitap Künyesi: Amy Mills (2014). Hafızanın Sokakları: İstanbul'da Peyzaj, Hoşgörü ve Ulusal Kimlik. Çeviren: Cem Soydemir. İstanbul: Koç Üniversitesi Yayınları. (ISBN: 9786055250249,344 sayfa).

"Mekân hazır bulduğumuz boş bir alan değildir; üretim/ tüketim ilişkileriyle yaratılan bir süreçte oluşur, üretim ilişkileri mekânı var eder." Haydi gerisini de ben tamamlayayım, "ya da yok eder". İnsanın mekânsallığı hakkında önemli kuramlar üreten Edward Soja, 2011'de İstanbul'da "Mekân ve Kültür" sempozyumunda bunları söylemiş, dünya nüfusunun hızla kentleştiğine dikkat çekmişti.

Bu bakımdan sosyal, politik, ekonomik ve kültürel alanda üretilen ve yeniden var edilen mekân, kolektif hafıza ile doğrudan bağlantılıdır. Ekonomi-politik boyutuyla “şehir” tartışmalarını yürüten David Harvey 2012'de İstanbul Bilgi Üniversitesi'nde yaptığı konuşmada kapitalizmin krizden çıkmak için "inşaat" sektörünü kullandığını söylemiş, özellikle "taşralaşma, şehir ve adalet" temasına yoğunlaşmıştı. Ben mekânın üretimi ve yok edilişi hakkındaki bu çerçeveye özellikle Türkiye bağlamında "mahalle" kavramının da eklenmesi gerektiğini düşünüyorum. "Mahalle", bize Osmanlı'dan miras kalan, biraz nostalji ile anılan yeni tarz rezidansların yükselmesiyle yeniden gündeme gelen ve belki de en çok "kentsel dönüşüme uğrayan" bir yaşam alanı. Mahalle biraz aile, biraz ulus, biraz bölge, biraz da dünya...

İstanbul gibi kendine has katmanları olan, "köy"lerden (Kadıköy, Bakırköy, Yeşilköy) ve "mahalle"lerden oluşan bir şehir, ince hafıza katmanlarına odaklanan mikro araştırmalar için ideal bir kaynak oluşturuyor. Küreselleşme literatürü, "şehir"e her geçen gün daha çok dönüştürme gücü atfetmekte. Şehir tarihçileri, beşeri coğrafyacilar, yerel idareciler giderek şehirlerin ve bölgelerin birer belirleyici aktör olarak ön plana çıktığını görüyorlar. Bu tartışmalar mikro alanlara indikçe ulus 
kimliğine alternatif olan alt-anlatılar su yüzüne çıkıyor. Türkiye'de bu bakımdan coğrafyacılara çok iş düşüyor. Dünyada sosyal bilimler paradigmalarını şehir ve mekân tartışmaları sayesinde yeniledi. Türkiye'de özellikle beşeri coğrafya çok disiplinli çalışmalara kendini açmalı ve böylece tıkanan yolları da açıklığa kavuşturmalıdır.

Amy Mills'in Koç Üniversitesi yayınlarından 2014 yılında "Hafızanın Sokakları: İstanbul'da Peyzaj, Hoşgörü ve Ulusal Kimlik" adıyla basılan araştırması millileşen bir kentin kültürel coğrafyaları üzerine bizi eleştirel bir geziye çıkarıyor. Durağımız Kuzguncuk. Bu semte dair bilmeyenler için birkaç tanıtıcı özellik sayacak olursak Kuzguncuk Boğazın Karadenize açılan Anadolu hattında Üsküdar'dan sonra gelir. En önemli özelliği İstanbul'da mahalle kültürünün devam ettiği nadir semtlerden olmasıdır. Tarihi evleri, ibadethaneleri, küçük kahveleri, firını, küçük dükkânlarıyla küçük ve samimi bir havası vardır. Kuzguncuk, manevi anlamda da Osmanlı'nın gayrimüslim cemaatleri için büyük değer taşır. Eskiden yolculuklar kolay olmadığından kutsal topraklara gidemeyen Yahudiler tarafindan Asya' daki ilk durak olarak kabul edilirmiş, bu yüzden Yahudiler burada yaşamak ya da buradaki mezarlığa gömülmek istemişler. Ana cadde İcadiye'den semte girince sol kolda Beth Ya'akov Sinagogu, yanında da Ayios Yeorgios Rum Ortodoks Kilisesi vardır. Daha ileride sağda da Ayios Panteleimon Kilisesi bulunur. Boğaz yolu üzerinde Kuzguncuk Camii, Ermeni Kilisesi Surp Krikor Lusavoriç'le yan yana yer alır. Söylenen o ki bu cami için Ermeni cemaati bahçelerinden yer vermişler. Kuzguncuk, yan yana yaşayan ve farklı inanış ve kültüre sahip grupların aynı mekânda nasıl farklı aidiyetler geliştirdiğine ve nasıl etkileşimde bulunduklarına bakabilmek için ideal bir mekândır.

Kuzguncuk'u bir beşeri coğrafyacı gözüyle ele alan Amy Mills ile 2012'de New York'taki Association of American Geographers konferansında yaptığım bir sunumda tanışmıştım; yazarın bir Amerikalı coğrafyacı olarak özellikle Türkiye'yi ele alması dikkatimi çekmişti. Amy Mills'in akademik kariyerine bakınca çok disiplinli bir formasyon görüyoruz. Mills, lisansını din bilimlerinde tamamlamış ve daha sonra Kahire'de Orta Doğu Kürsüsünde lisansüstü derecesini almış. Doktorasını ise Amerika'da Texas /Austin'de coğrafya bölümünde tamamlamış. Sözünü ettiğim çok boyutluluk aynı zamanda Mills'in araştırma yöntemine de yansımış; beşeri anlamda insan- coğrafya ilişkisine bakarken etnografik yöntemi kullanmış. Aşina olmadığı bir kültüre bakarken etnografik yöntem kullanması sayesinde hem bütünsel (holistic) açıdan konuya bakabilmiş hem de kültürel göreceliliği kapsayan, diyalojik, karşılaştırmalı ve yorumsamacı (hermeneutic) analizler yapabilmiş.

Bilindiği gibi etnografik analiz gücünü sadece kullandığı teknikten değil, etnografların bilgi birikimi ve deneyiminden, kısacası sahadaki insan kaynağının niteliklerinden almaktadır. Geçerli ve güvenilir bilgi üreten esaslı etnografik araştırmalar antropoloji eğitiminden, kuramsal ve yöntembilimsel yetkinlikten, karşılaş̧ırmalı etnolojik verilere hâkimiyetten doğmuştur. Bu nedenle etnografik bakış kültürel görecelilik ve mekânsallık bağına bakan araştırmalar için ideal bir tartışma evreni yaratır.

Belli ki Mills için beşeri coğrafya ve mekân kuramlarını test etmek bakımından Türkiye örneği zengin bir araştırma kaynağı olmuş. Ben de "vatan" kavramı üzerine 
çalıştığım için kendisiyle Osmanlıdan kalan imparatorluk mirasının nasıl ulus devlet mekânında temsil edildiğine dair kısa bir sohbet yaptığımızı anımsıyorum. Geçmişin bugünde ve mekândaki temsili/yansımasına dair çalışmaların daha çok yapılması gerektiğini düşündüğüm ve bu konuda coğrafyacılara, antropologlara, sosyologlara, felsefecilere ve siyaset bilimcilere iş düștügü kanaatinde olduğum için Mills'in bu çalışmasının Türkçe'ye çevrilmesini çok önemli buluyorum. Ayrıca çevirmen Cem Soydemir mekânsallığa dair kavramları tam yerinde kullanarak Türkçe literatüre çok değerli bir katkı yapmış, bunu da vurgulamadan geçemeyeceğim.

Osmanlı'dan Türkiye'ye geçiş sürecine bakan Mills, şehrin hafızasında ve mekânında egemen ve alternatif söylemlere dair analiz yaparken, odağını gündelik yaşamın aktörlerine çeviriyor. Mills' in Kuzguncuk'a dair çalışması bize bu kaynağın zenginliğini gösteren çok önemli bir araştırma. Neden? Çünkü daha önce de belirttiğimiz gibi Kuzguncuk ilk bakışta üç semavi dinin sembollerini taşıyan, yan yana duran farklı tarzda mimarisi ve çok kültürlü insan dokusuyla öne çıkan bir mekân. Son dönemde Kuzguncuk Bostanı, (semtlilerin dilindeki adıyla İlia'nın Bostanı) yeşil alanların korunması isteyenler ve inşaat-betonlaşma yanlısı olanlar arasındaki gerilime de sahne olmuştu. Aynı zamanda Kuzguncuk yukarıda referans verdiğimiz Soja'nın ve de Harvey'in üzerinde durduğu kültürel ve sosyo-ekonomik boyutları çok güzel örnekliyor. Hem kentsel dönüşümden payını alan hem de Osmanlı'nın çok kültürlülüğünü yansıtan bu semtin Mills'in dikkatini cezbetmesine şaşmamak gerek. Mills bu boyutlara ek olara bir de feminist coğrafya'yı işin içine katarak mekân ve beşeri coğrafya tartışmasını zenginleştiriyor.

Mills, Kuzguncuk gibi farklı dini kültürel ve sosyal aidiyetlerin barındığı mahalleye bakarken gayrimüslimlere dair kentsel peyzaj, kozmopolitizm nostaljisi, yuva, kolektif hafıza gibi kavramlarla çalışmış. Özellikle vurgulamak gerekir ki araştırmac1 "paradoksal mekân" (s.65) kavramından güç alarak "kamusal ve özel alanda, merkezde ve uçta bir bireyin birden fazla ve karışık kimlikli kategorilerde nasıl ikamet edebildiğini mekânsal bakımdan ele almış. Bu da bize coğrafyanın kendi iç mantığından bakıldığında birden fazla aidiyetin bir bireyde bile nasıl barındığını ve nasıl katmanlaştığını gösteriyor.

Mekânsal düşünme şekli sayesinde ulusal kimlik gibi yaygın ve egemen anlatıları "mahalle" gibi mikro alanlardan bakarak sorgulayabiliyoruz. Kitap yedi bölümden oluşuyor. İlk bölümde peyzaj, kimlik ve şehrin kültürel coğrafyasına kuramsal bir giriş yapılmış. Daha sonraki beş bölümde öne çıkan sokaklar ve mahalleler ve onları temsil ettiği kavram ve değerlere (komşuluk, yuva nostaljisi, kolektif hafiza) yer verilmiş. Görüşülen kişilerin anlattığı deneyimler, gözlemler ve saptamalara yer verilmiş. Kavramsal tartışma özellikle kitabın beşinci ve altıncı bölümleri öne çıkıyor. Bu bölümler "paradoksal mekân" kavramına örnek teşkil eden örneklerle dolu, çünkü beşinci bölüm toplumsal cinsiyetin mekânsallaşma biçimlerini feminist coğrafya üzerinden okuyor; altıncı bölüm ise etnik ve dini kimlikler üzerinden mekânsallığa bakıyor. Bireyin çoklu aidiyetlerini ve "kimliklenme" süreçlerini, hem Türk hem azınlık olması, hem mahalleli hem dışarıdan olma halini bu örnekler üzerinden okumak mümkün. Yedinci bölüm ise İstanbul'daki kozmopolitizm nostaljisinin dayanakları ve gerçekliği sorgulanıyor. Nostalji kavramı acaba ulus devletin tektipleştirici mekânsallığında kaybedilen çeşitliliğin arkasından samimi bir yakınma mı yoksa milliyetçiliği yeniden üreten bir gölge oyunu mu? Bu sorulara bireysel ve kolektif hafizadan gelen verilerle yanıt aranıyor. 
Mahalle ve sokak kavramlarını kolektif hafiza mekânları olarak ele alan araştırmacı mahalleyi hem dar anlamda bir aile simülasyonu hem de geniş anlamda ulusal kimliğin taşıyıcı mekânı olarak analiz etmiş. Bir bakıma şehirdeki ulusa, mahalledeki şehre, sokaktaki mahalleye bakmış. Kendi deyimiyle "insanların millileşen bu şehirde nasıl yaşadıklarını ve Türkleştirmenin yarattığı etkinin ardından devletin ulus tahayyülünü nasıl anlamlandırdıklarını" inceliyor.

Mills' in çalışmasında eksik bulduğum tek şey bizzat mahalle kavramının tartışılması ve Osmanlı'dan bu yana geçirdiği sosyo-politik ve coğrafi anlam kaymalarına yer vermeyişi oldu. Belki de Türkçe ve Osmanlıca literatürün kısaca taranması ve sahada görüşülen kişilere "mahalle"den ne anladıklarının sorulması konuya zenginlik katardı. Yazının başında belirttiğim gibi Mahalle, biraz aile, biraz ulus, biraz bölge, biraz da dünya... Osmanlı'dan bu yana mahalle şehir kültürü içinde kendine özgü anlamlar içerir. Prof. Dr. Şerif Mardin'in altını çizdiği gibi mahalle, "baskısıyla" maruftur; Foucault'cu çerçeveden bakacak olursak "şeffaflığıyla, görme/görülme yeri" olmasıyla adeta bir pan-opticon dur. Çok katmanlıdır, hem öznel hem nesneldir ve bir o kadar da politik bir mekândır. Örneğin Kadı Şeriye Sicilleri 'nde Mahalle üç farklı anlamda karşımıza çıkar. Birincisi, idari birim olarak, yani vergi toplama işinin temel dayanağı olarak ikamet/mahal. İkincisi doğduğumuz yer anlamında mahal. Üçüncüsü ise sosyo-etnik kimlik ve aidiyet birimi olarak mahalle yani millet sistemindeki sosyal dayanışma ve örgütlenme mekânı olarak mahal/tesanüt... Bütün bu anlamlar Mills' in araştırmasında yansımasını bulabilirdi.

Bence çalışmanın en kuvvetli yönü mikro aidiyetlerin anlamı üzerinden (Kuzguncuklu olmaya yüklenen anlamın) "paradoksal mekân" tartışmasını açması ve etnografik olarak kolektif hafizada yer etmiş "hoşgörü ve nostalji" üzerinden kozmopolitizmin arkasına saklanan milliyetçiliğe dair bir tartışmaya 1şık tutması. Daha nice örneklerini görmek dileğiyle... 